\title{
STUDY ON THE USE OF TOMATO VINES IN RUMINANT FEEDING \\ 2- EFFECT OF USING TREATED TOMATO VINES ON RUMEN FERMENTATION AND DAIRY COWS PERFOMANCE
}

\author{
EL-SAYED, H.M. ${ }^{1}$, Z.H. ABD EL-HAMID ${ }^{1}$, EL-SH. M. RAMADAN ${ }^{1}$, \\ M.H.M. YACOUT ${ }^{2}$ and H.EL-S. ABBAS ${ }^{2}$
}

1. Faculity of Agricultural, Ain-Shams University, Egypt.

2. Animal Production Research Institute, Agricultural Research Center, Dokki, Giza, Egypt

(Manuscript received 18 July 2012)

\begin{abstract}
Twelve crossbred Friesian cows were used in double $6 \times 6$ Latin square design, each period lasting 28 days. They were fed according to their body weight $(550 \pm 10.50 \mathrm{~kg}$ in average) and previous milk yield (10 - $12 \mathrm{~kg} /$ day average) on tomato haulms in fresh form (FTH), hay $(\mathrm{HTH})$, hay treated with fungus, (Trichoderma reesei, $\mathrm{HTH}+\mathrm{F}$ ) or tomato haulm silage (STH) or tomato haulm

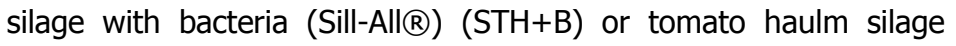
with dried yeast $(\mathrm{STH}+\mathrm{B}+\mathrm{Y})$ in addition to concentrate feed mixture (CFM). While three other females sheep fitted with permanent rumen fistula were used for rumen fermentation and in situ studies. Sheep were offered silage adlibitum plus 750 (g/head/d) CFM for fermentation trials, while cows were fed $8 \mathrm{~kg} /$ head / day of CFM in addition to dry yeast (DY) ( $5 \mathrm{~g} /$ head for sheep and $10 \mathrm{~g} /$ head for cow) with feeding $\mathrm{TH}$ silage with bacteria. Animals fed treated $\mathrm{TH}$ with fungi or silage without bacteria had higher NH3-N concentration, while those fed on $\mathrm{STH}+\mathrm{B}$ or $\mathrm{STH}+\mathrm{B}+\mathrm{Y}$ had higher TVFA's. Higher MP was recorded with $\mathrm{HTH}+\mathrm{F}$ or $\mathrm{STH}+\mathrm{B}+\mathrm{Y}$. Soluble, insoluble fraction and $\mathrm{DE}$ of $\mathrm{DM}$, $\mathrm{OM}$, and $\mathrm{CP}$ were higher for animals fed $\mathrm{HTH}+\mathrm{F}$ or $\mathrm{STH}+\mathrm{B}+\mathrm{Y}$. All of these were reflected on the more milk and 4\% FCM yield, while concentrations of residue of pesticides were dramatically decreased. Picture of blood showed an increase in glucose, cholesterol. Globulin, urea, creatinin, AST and ALT with untreated $\mathrm{TH}$, while all these parameters decreased following fungus treatment or ensilage TH with bacteria and DY. Based on that, it is recommended to treat $\mathrm{TH}$ with fungi or incited it especially with $B+D Y$. Were more effective in animal performance.

Key words: tomato haulms, cow, milk yield, degradability, pesticides residues, fungus treatment, silage.
\end{abstract}

\section{INTRODUCTION}

In Egypt and through the limited agricultural land and growing population has become highly competitive on the board of agricultural production of food for humans and animals. With the continuation of a deficit in feed resources available and which is estimated annually by about 2.5 million tons of food indigestible, equivalent to 6 million tons of feed. Since the availability of feed resources is imperative for the 
advancement of livestock, the best way to achieve this goal is to take advantage of food that have not been used in animal nutrition, a field crop residues. Crop area is estimated to yield about 537,582 acre tomato (Lugs early summer, summer, winter and Nelly) produce about $1,720,262$ tons of tomatoes vines are expected to reach this amount of thrones to weaknesses in the case of cultivation of new varieties of tomatoes. Ministry of Agriculture (2006/2007).

There are three types of pesticide degradation, microbial, chemical, and photo degradation. Microbial degradation is the breakdown of pesticides by fungi, bacteria, and other microorganisms that use pesticides as a food source (DebMandal et al., 2008).

This study aimed to use fresh or treated Tomato vines in animal feeding and its effect on rumen fermentation and dairy cows performance.

\section{MATERIALS AND METHODS}

Twelve crossbred Friesian cows in their third and fourth lactation seasons were used in double $6 \times 6$ Latin squares design with each period lasting 28 day. Cows were paired according to body weight $(550 \pm 10.50 \mathrm{~kg}$ in average and previous milk records (average 10-12 kg/day). Two cows were fed one of the six experimental rations composed of the following:-

1- Fresh tomato haulm + Concentrate feed mixture (CFM) (control). (FTH) 2-Hay tomato haulm + Concentrate feed mixture (CFM). (HTH). 3-Hay tomato haulm treated with fungus (Trichoderma reesel). (HTH+F). 4-Tomato haulm silage without additives (STH). 5-As group $4+$ Sill-all bacteria (STH+B). 6-As group $5+$ dried yeast $(\mathrm{STH}+\mathrm{B}+\mathrm{Y})$.

Eighteen adult barki rams of about two years old and $50 \pm 2 \mathrm{~kg}$ body weight were divided into six similar groups ( 3 in each) consecutively and used to carry out six metabolic trials. Preliminary period lasted 21 days followed by 7 days as collection period. Animals were fed $750 \mathrm{~g}$ CFM to supply the CP requirements according to NRC (1990), while, rations were allowed to be fed ad libitum in each group, and the actual amount of tomato haulm (TH) was recorded. Mineral salt blocks were available for the animal. Concentrate feed mixture was offered twice daily at 10.0 a.m and 4.00 p.m., while free amount of water was offered.

Fecal samples were dried at $60^{\circ} \mathrm{C}$ for $72 \mathrm{~h}$, feed and fecal samples were ground through $1 \mathrm{~mm}$ screen on a Wiley mill grinder and the samples $(50 \mathrm{gm} / \mathrm{sample} /$ treatment/sheep) were preserved for analysis. The samples were analyzed for crude protein (CP), crude fiber (CF), ether extract (EE) and ash, according to AOAC (1990). 
Total digestible nutrients (TDN) and digestible crude protein were calculated according to Maynard et al. (1978) on a dry matter basis (DM).

Cell wall was analyzed for neutral detergent fiber (NDF), acid detergent fiber (ADF) and acid detergent lignin (ADL) using Tecator Fibretic system. Hemicellulose and cellulose were determined by difference according to Van Soest (1982).

During a period of 28 days whereas the first 21 days as preliminary period followed by a 7-days collection period, milk yield was recorded individually on two successive days, milk samples were collected twice daily for 7 collection days through the collection period from all cows. Milk samples were chemically analyzed for total solid (TS), protein, fat and ash according to AOAC (1990) while lactose was calculated by difference.

Three fistulated ewes $(48.50 \pm 1.0 \mathrm{~kg} \mathrm{BW})$ were used to carry out the rumen fermentation trials. Samples of rumen liquor were taken at 0,3 and $6 \mathrm{~h}$ post feeding in order to immediately determine same parameters. Samples were strained through four layers of chesses cloth, then ammonia nitrogen $\left(\mathrm{NH}_{3}-\mathrm{N}\right)$ was determined by using magnesium oxide (MgO) as described by AOAC (1990). Concentration of total volatile fatty acid (TVFA's) was estimated as well by using steam method using Cr-EDTA according to EL-Shazly et al. (1976)

In situ degradation data for $\mathrm{DM}, \mathrm{OM}$ and $\mathrm{CP}$ were fitted to the equation of Ørskov and McDonald (1979) where: $\mathrm{P}=\mathrm{a}+\mathrm{b}\left(1-\mathrm{e}^{-\mathrm{ct}}\right) \mathrm{P}$ is a degradation rate at time $t$, $a$ is the intercept representing the soluble fraction of DM, OM and CP (time 0), $b$ is the portion of DM, OM and CP potentially degraded in the rumen, $c$ is a rate constant of degradation of fraction $b$. The ruminally un-degraded fraction $M=100$ ( $a+b)$, lag time (LT) was estimated according to McDonald (1981). The effective degradability (ED) for tested mixture was estimated from the equation of Ǿrskov and McDonald (1979) as follow: ED $=a+b c /(c+k)$ where, $k$ is the out- flow rate assumed to be $0.05 / \mathrm{h}$ under the feeding condition in the current study.

Serum cholesterol was determined by colorimetric method of Stein (1986), and serum total protein (TP) according to Henry and Todd. (1974). function was determined by measuring blood urea using the colorimetric methods of Henry and Todd (1974).

\section{Pesticide Residues Analysis}

Pesticide residues analysis in feed and milk samples was carried out as described The analytical standards of the tested pesticides were kindly provided by Central Laboratory of Residue Analysis of Pesticides and Heavy Metals and Food, Agricultural Research Center, Ministry Of Agriculture. The selected analytical standards 
are: (a) - Halogenated hypothyroids: Cypermethrin, lambda-cyhalothrin. (b)Organophosphorus insecticides: Dimethoate, Malathion. (c)- Chlorinated hydrocarbon insecticides: HCB, lindane, p, p'-DDD, p-p' DDE and p-p' DDT.

A simple multi-residue method according to Kadenczki et al. (1992) was applied to extract several pesticides (chlorinated hydrocarbon, halogenated pyrothriod insecticides and organophosphate) from tomato haulms. The principle of this method is based on having a homogenous sample pulp adsorbed on the surface of activated florisil to obtain a free-flowing powder, which is extracted in a glass column with methylene chloride-acetone $(9+1, \mathrm{v} / \mathrm{v})$. The gas chromatograph (GC) used was HP5890 Series II.Solvents and other reagents used (acetone, benzene, ethyl acetate, methylene chloride, $\mathrm{n}$-hexane, florisil 60-100 mesh (pre-treated as in the method of Kadenczki et al. (1992), sodium hydroxide, stannous chloride, carbon disulfide, cupric acetate monohydrate, hydrochloric acid, ethanol, diethanol amine were analytical reagent grade.

A simple multi-residue method according to Kadenczki et al. (1992) was used to extract several pesticides (chlorinated hydrocarbon, halogenated pyrothriod insecticides and organophosphate) in milk. The principle of this method is based on having a homogeneous sample pulp adsorbed on the surface of activated florisil to obtain a free-flowing powder, which is extracted in a glass column with methylene chloride-acetone $(9+1, \mathrm{v} / \mathrm{v})$. The gas chromatograph (GC) used was HP-5890 Series II.

\section{Statistical Analysis}

All data of milk yield, milk composition, pesticides residues and blood biochemical constituents were subjected to statistical analysis of variance using a completely randomized and Latin square designs. Means were calculated for all variables by cow within period. Data were analyzed using the MIXED procedure of SAS (SAS, 1999). Period and cow were considered random effects, diet and cannulation effects were considered fixed. Estimation method was restricted maximum likelihood and the degrees of freedom method was (SAS, 1999). Differences were tested using the PDIFF option in SAS (SAS, 1999) using a protected $(P<0.10)$ LSD test. Differences were declared significant at a $P<0.05$. 


\section{RESULTS AND DISCUSSION}

\section{Rumen fluid parameters}

Table. 1. Chemical analysis and cell wall constituents of the concentrate feed mixture CFM) untreated and treated tomato haulm fed to animals (on DM basis)

\begin{tabular}{|c|c|c|c|c|c|c|c|}
\hline Item & CFM & FTH & HTH & HTF & HTS & THS+B & $\begin{array}{c}\text { THS+B+D } \\
\text { Y }\end{array}$ \\
\hline DM & 88.95 & 29.68 & 89.66 & 87.85 & 31.66 & 31.87 & 32.2 \\
\hline OM & 93.32 & 91.07 & 91.03 & 86.21 & 91.01 & 90.80 & 92.34 \\
\hline CP & 15.88 & 7.83 & 14.88 & 19.69 & 7.67 & 7.69 & 8.12 \\
\hline CF & 6.72 & 42.75 & 43.59 & 35.83 & 40.69 & 38.32 & 37.22 \\
\hline EE & 2.83 & 1.77 & 1.85 & 1.56 & 1.72 & 1.75 & 1.88 \\
\hline NFE & 67.89 & 39.72 & 30.71 & 41.15 & 40.93 & 41.72 & 45.12 \\
\hline Ash & 6.68 & 8.93 & 8.97 & 13.79 & 8.99 & 10.52 & 7.66 \\
\hline NDF & 24.92 & 76.54 & 69.77 & 62.60 & 64.39 & 61.39 & 60.10 \\
\hline ADF & 12.33 & 49.05 & 46.42 & 39.32 & 41.96 & 36.96 & 33.12 \\
\hline ADL & 9.56 & 22.08 & 19.28 & 17.07 & 17.80 & 16.91 & 15.40 \\
\hline Hemi cellulose & 12.59 & 27.49 & 23.35 & 23.28 & 22.43 & 23.91 & 21.00 \\
\hline Cellulose & 2.77 & 26.97 & 27.14 & 22.25 & 24.16 & 21.78 & 19.20 \\
\hline
\end{tabular}

CFM: Concentrate feed mixture (33\% yellow corn, $5 \%$ soyabean meal, $20 \%$ wheat bran, $17 \%$ rice bran, $17 \%$ undecorticated cotton seed meal, $4.5 \%$ molasses, $2 \%$ salt, $0.5 \%$ mineral mixtures), FTH: Fresh tomato haulm, HTH: Hay tomato haulm, THF: Hay tomato haulm treated with fungi, THS: Tomato haulm silage, THS+B: Tomato haulm silage with bacteria, THS+DY: tomato haulm silage with dried yeast.

No significant differences were noticed for ruminal $\mathrm{pH}$ of ewes fed the experimental diets (Table, 2). Ewes fed TH either treated with the fungus or in the form of silage (without any additions) showed higher $(\mathrm{P}<0.05) \mathrm{NH}_{3}-\mathrm{N}$ concentrations. While animals fed fresh $\mathrm{TH}$ had the lower $\mathrm{NH}_{3}-\mathrm{N}$. These could be explained by the more proteolytic activity (Ørskov, 1992) and the more CP digestibility and feed intake. Those fed FH could have less feed intake which may be depressed as results of higher content of pesticides. 
Ruminal total VFA's concentration was higher $(P<0.05)$ for ewes fed $S T H+B$ or $\mathrm{STH}+\mathrm{B}+\mathrm{Y}$ compared to the $\mathrm{FH}$ one and other to the more $\mathrm{CF}$ digestibility in the mean time, it reflected on less rate of out follow compared to the fresh group. In these connection Kumar et al. (1997) found high concentration of TVFA's in the rumen fluid when biological-treated roughages were fed, they attributed such increase to the high fiber breakdown. Yeast supplementation led to a significant increase of ruminal bacteria. So ewes fed diets contained $\mathrm{HTH}+\mathrm{F}$ or $\mathrm{STH}+\mathrm{B}+\mathrm{Y}$ showed higher $(P<0.05)$ microbial protein synthesis. However microorganism uses the pesticide as a carbon and energy source Allam et al. (2006) reported that the VFA's concentration in rumen is governed by several factors such as DM digestibility, rate of absorption, rumen $\mathrm{pH}$, transportation of the digest from the rumen to other parts of the digestive tract and the microbial population in the rumen and their activities.

Yeast supplementation led to significant increase of ruminal bacteria (Wallace and Newbold, 1993) and microbial flow from the rumen. Yeast supplementation increase numbers of ruminal cellulolytic bacteria and their activities, which could increase forages degradability and increase the flow rate of microbial protein as well as may alter the patterns of VFA's formation Yeast is also observed to stimulate cellulolytic bacteria in the rumen, increase fiber digestion and flow of microbial protein from the rumen. However, the fungus had the ability to decompose ligno-cellulose containing materials which increase the availability of carbohydrates in order to produce more proteins (DebMandal et al., 2008). So ewes fed diets contained HTF or $\mathrm{TH}+\mathrm{B}+\mathrm{DY}$ showed higher $(\mathrm{P}<0.05)$ microbial protein synthesis. However, microorganisms could use pesticides as a carbon and energy source. 
Table. 2. Rumen liquor parameters total VFA's and microbial nitrogen synthesis for sheep fed the experimental rations (mean \pm SE)

\begin{tabular}{|l|c|c|c|c|c|c|}
\hline \multicolumn{1}{|c|}{ Item } & FTH & HTH & HTH+F & SHT & STH+B & STH+B+Y \\
\hline $\mathrm{pH}$ & $6.12 \pm 0.93$ & $5.12 \pm 0.63$ & $5.18 \pm 0.31$ & $5.21 \pm 0.50$ & $5.32 \pm 0.52$ & $5.35 \pm 0.58$ \\
\hline $\mathrm{NH}_{3}-\mathrm{N}(\mathrm{mg} / 100 \mathrm{ml})$ & $10.30 \pm 0.56^{\mathrm{d}}$ & $12.21 \pm 0.24^{\mathrm{c}}$ & $15.30 \pm 0.54^{\mathrm{a}}$ & $13.02 \pm 0.04^{\mathrm{c}}$ & $14.30 \pm 0.23^{\mathrm{b}}$ & $14.50 \pm 0.24^{\mathrm{b}}$ \\
\hline Total VFA's (meq./100 ml) & $7.24 \pm 0.46^{\mathrm{d}}$ & $8.94 \pm 0.14^{\mathrm{c}}$ & $11.21 \pm 0.47^{\mathrm{b}}$ & $11.18 \pm 0.34^{\mathrm{b}}$ & $12.20 \pm 0.11^{\mathrm{a}}$ & $12.30 \pm 1.98^{\mathrm{a}}$ \\
\hline Rumen volume (L) & $2.62 \pm 0.52^{\mathrm{d}}$ & $2.93 \pm 0.29^{\mathrm{d}}$ & $4.03 \pm 0.18^{\mathrm{b}}$ & $3.78 \pm 0.18^{\mathrm{c}}$ & $4.20 \pm 0.47^{\mathrm{a}}$ & $4.25 \pm 0.33^{\mathrm{a}}$ \\
\hline Rates of outflow (\% hr) & $7.33 \pm 0.48^{\mathrm{a}}$ & $6.5 \pm 0.44^{\mathrm{b}}$ & $5.42 \pm 0.58^{\mathrm{c}}$ & $6.88 \pm 0.47^{\mathrm{b}}$ & $6.90 \pm 0.55^{\mathrm{b}}$ & $6.95 \pm 0.15^{\mathrm{b}}$ \\
\hline Microbial nitrogens (g/h/d) & $9.66 \pm 0.49^{\mathrm{e}}$ & $14.87 \pm 0.67^{\mathrm{d}}$ & $32.86 \pm 0.59^{\mathrm{a}}$ & $18.40 \pm 0.19^{\mathrm{c}}$ & $28.50 \pm 0.36^{\mathrm{b}}$ & $30.40 \pm 1.98^{\mathrm{a}}$ \\
\hline
\end{tabular}

abcde Means within rows with different superscripts are significantly different $(P<0.05)$

FTH: Fresh tomato haulm, HTH: Hay tomato haulm, HTH+F: Hay tomato haulm treated with fungi, STH: Tomato haulm silage, STH+B: Tomato haulm silage with bacteria, STH+B+Y: tomato haulm silage with bacteria+ dried yeast.

\section{Kinetics Degradation}

It is very clearly that biologically treated TH either with the fungus or in silage form could resulted in better $(\mathrm{P}<0.05)$ soluble fraction $(a)$, potentially fraction $(P<0.05)$ and effective degradability (ED \%) of the experimental diets (Table 3$)$ for DM, OM and CP contents. Soluble fraction (a) was increased by 30.51, 19.05 and $24.65 \%$ with the fungus treated of $\mathrm{TH}$ for the (a) degraded of $\mathrm{DM}, \mathrm{OM}$ and $\mathrm{CP}$, respectively, while ensiling of $\mathrm{TH}$ with (B+DY) was resulted in an increase of soluble fraction of DM, OM and CP by $24.17,14.76$ and $23.82 \%$, respectively. The same trend was found for fraction (b), it increased by 27.87 for (DM), 18.35 for (OM) and $26.15 \%$ for (CP) followed with the fungi treatment of $\mathrm{TH}$. The corresponding increase of fraction (b) followed with the ensiling of TH with (B+DY) was 22.80 for (DM), 14.76 for (OM) and $23.82 \%$ for (CP), respectively. However, treatment of $\mathrm{TH}$ with the fungus was resulted in an increase of the effective degradability (ED) of DM.OM and $\mathrm{CP}$ followed by ensiling $\mathrm{TH}$ with ( $\mathrm{B}+\mathrm{DY}$ ) compared to the untreated $\mathrm{TH}$ on its without or with bacteria alone. This finding agrees with those reported by El-Waziry and Ibrahim (2007), who reported when LAB and DY were combined together, the soluble and insoluble fractions increased and the effective degradability was also increased by 17.42 and 15.48 for DM and OM of the treated materials against the untreated one, respectively. These could be due to the synchronization effect of DY and LAB together on the function of the cell wall of such materials and decreased concentrations of all phytonutrients. So, it means that when citrus pulp was conserved in silage with $L A B$ and DY supplementation together. However, it seems the no effect of inoculants 
treatment, DY and their interaction on any of degradation kinetic and the effective degradability for crude protein. The great degradative effect of the rumen microorganisms helps the animal to tolerate considerable concentrations of the pesticides.

Table. 3. Degradation kinetics of DM, OM and CP for experimental tomato haulms for sheep fed the experimental rations (mean $\pm \mathrm{SE}$ )

\begin{tabular}{|c|c|c|c|c|c|c|}
\hline Item & FTH & HTH & $\mathrm{HTH}+\mathrm{F}$ & SHT & $\mathrm{STH}+\mathrm{B}$ & $\mathrm{STH}+\mathrm{B}+\mathrm{Y}$ \\
\hline \multicolumn{7}{|l|}{ DM } \\
\hline$a, \%$ & $19.40 \pm 0.12^{b}$ & $18.89 \pm 0.48^{c}$ & $25.32 \pm 0.48^{a}$ & $22.23 \pm 0.39^{a}$ & $23.41 \pm 0.19^{\mathrm{a}}$ & $24.09 \pm 0.39^{a}$ \\
\hline$b, \%$ & $25.13 \pm 0.27^{c}$ & $26.32 \pm 0.14^{c}$ & $32.14 \pm 0.19^{\mathrm{a}}$ & $30.04 \pm 0.20^{\mathrm{b}}$ & $31.44 \pm 0.19^{\mathrm{a}}$ & $32.11 \pm 0.27^{\mathrm{a}}$ \\
\hline$a+b, \%$ & $44.53 \pm 0.14^{b}$ & $45.21 \pm 0.19^{b}$ & $57.46 \pm 0.27^{\mathrm{a}}$ & $52.27 \pm 0.45^{\mathrm{a}}$ & $34.85 \pm 0.18^{d}$ & $56.20 \pm 0.48^{\mathrm{a}}$ \\
\hline$c, \%$ & $0.054 \pm 0.001$ & $0.056 \pm 0.001$ & $0.055 \pm 0.002$ & $0.054 \pm 0.001$ & $0.056 \pm 0.002$ & $0.058 \pm 0.002$ \\
\hline U & $55.57 \pm 0.37^{\mathrm{a}}$ & $54.79 \pm 0.18^{a}$ & $42.54 \pm 0.48^{c}$ & $47.73 \pm 0.37^{b}$ & $45.15 \pm 0.27^{b}$ & $43.800 .18^{c}$ \\
\hline EDDM 3, \% & $35.56 \pm 0.18^{b}$ & $36.03 \pm 0.56^{b}$ & $46.12 \pm 0.31^{a}$ & $41.54 \pm 0.22^{\mathrm{a}}$ & $43.88 \pm 0.14^{a}$ & $45.26 \pm 0.18^{a}$ \\
\hline \multicolumn{7}{|l|}{ OM } \\
\hline$a, \%$ & $20.99 \pm 0.27^{b}$ & $20.89 \pm 0.14^{b}$ & $24.99 \pm 0.31^{\mathrm{a}}$ & $23.62 \pm 0.18^{b}$ & $23.88 \pm 0.48^{b}$ & $24.09 \pm 0.27^{a}$ \\
\hline b, \% & $31.54 \pm 0.37^{b}$ & $32.14 \pm 0.14^{b}$ & $37.33 \pm 0.27^{\mathrm{a}}$ & $33.91 \pm 0.14^{b}$ & $34.18 \pm 0.22^{\mathrm{a}}$ & $35.20 \pm 0.18^{\mathrm{a}}$ \\
\hline$a+b, \%$ & $52.53 \pm 0.18^{c}$ & $53.03 \pm 0.48^{c}$ & $62.32 \pm 0.37^{\mathrm{a}}$ & $37.53 \pm 0.27^{d}$ & $58.06 \pm 0.18^{b}$ & $59.29 \pm 0.12^{b}$ \\
\hline$c, \%$ & $0.050 \pm 0.001^{a}$ & $0.053 \pm 0.001^{a}$ & $0.056 \pm 0.001^{a}$ & $0.054 \pm 0.001^{a}$ & $0.055 \pm 0.001^{a}$ & $0.056 \pm 0.001^{a}$ \\
\hline u & $47.47 \pm 0.12^{\mathrm{a}}$ & $46.97 \pm 0.13^{\mathrm{a}}$ & $37.68 \pm 0.21^{c}$ & $42.47 \pm 0.12^{b}$ & $41.94 \pm 0.18^{b}$ & $40.71 \pm 0.14^{b}$ \\
\hline EDDM 3, \% & $25.50 \pm 0.21^{\mathrm{c}}$ & $41.41 \pm 0.24^{b}$ & $49.30 \pm 0.28^{\mathrm{a}}$ & $54.42 \pm 0.21^{\mathrm{a}}$ & $45.49 \pm 0.17^{\mathrm{a}}$ & $47.01 \pm 0.23^{\mathrm{a}}$ \\
\hline \multicolumn{7}{|l|}{$\mathrm{CP}$} \\
\hline$a, \%$ & $22.45 \pm 0.22^{b}$ & $22.50 \pm 0.17^{b}$ & $28.03 \pm 0.23^{\mathrm{a}}$ & $26.31 \pm 0.18^{\mathrm{a}}$ & $27.14 \pm 0.24^{\mathrm{a}}$ & $27.81 \pm 0.19^{\mathrm{a}}$ \\
\hline$b, \%$ & $31.17 \pm 0.21^{\mathrm{c}}$ & $34.73 \pm 014^{c}$ & $42.21 \pm 0.31^{\mathrm{a}}$ & $37.09 \pm 0.27^{b}$ & $38.18 \pm 0.36^{b}$ & $39.87 \pm 0.27^{b}$ \\
\hline$a+b, \%$ & $53.62 \pm 0.24^{c}$ & $57.23 \pm 0.19^{c}$ & $70.24 \pm 0.31^{\mathrm{a}}$ & $63.40 \pm 0.23^{b}$ & $65.32 \pm 0.20^{\mathrm{b}}$ & $67.68 \pm 0.21^{b}$ \\
\hline$c, \%$ & $0.050 \pm 0.001^{b}$ & $0.050 \pm 0.001^{b}$ & $0.055 \pm 0.001^{\mathrm{a}}$ & $0.053 \pm 0.001^{a}$ & $\begin{array}{l}0.055 \pm 0.001 \\
\mathrm{a}\end{array}$ & $0.056 \pm 0.001^{a}$ \\
\hline U & $46.38 \pm 0.12^{\mathrm{a}}$ & $42.77 \pm 0.14^{\mathrm{a}}$ & $29.76 \pm 0.21^{\mathrm{c}}$ & $36.60 \pm 0.19^{b}$ & $34.680 .27^{b}$ & $32.320 .17^{b}$ \\
\hline EDDM 3, \% & $41.93 \pm 0.33^{\mathrm{b}}$ & $44.21 \pm 0.19^{\mathrm{b}}$ & $55.34 \pm 0.23^{\mathrm{a}}$ & $49.99 \pm 0.18^{\mathrm{b}}$ & $51.84 \pm 0.23^{\mathrm{a}}$ & $53.77 \pm 0.27^{\mathrm{a}}$ \\
\hline
\end{tabular}

abcd Means within column with different superscript are significantly differ $(P<0.05)$.

FTH: Fresh tomato haulm, HTH: Hay tomato haulm, HTH+F: Hay tomato haulm treated with fungi, STH: Tomato haulm silage, STH+B: Tomato haulm silage with bacteria, STH+B+Y: tomato haulm silage with bacteria+ dried yeast.
$\mathrm{a}=$ soluble fraction $(\%)$.
$\mathrm{c}=$ rate of degradability $(\% \mathrm{~h}-1)$

$b=$ potentially degradable fraction (\%).

$\mathrm{U}=$ rumen undegradable fraction $\{100-(\mathrm{a}+\mathrm{b})\}$.

$\mathrm{ED}=$ effective degradability (\%). 


\section{Milk Yield and composition}

Animals fed ration contained TH either treated with the fungi or $\mathrm{B}+\mathrm{DY}$ showed more $(P<0.05)$ milk yield and fat corrected milk 4\% $(F C M)$ compared to the other experimental rations (Table 4). However, the increase of milk yield or $4 \%$ FCM was reached 37.34 and $47.17 \%$ by the fungus treatment, while this increase was 35 and $44.56 \%$ by ensiling with B+DY. It is well known that the fungus had the capability to produce the enzyme cellulase, who could break-down of cellulose to glucose (Nevalainen et al., 1991), in the mean time the pesticides was degraded and improved DM intake Jouany and Morgavi (2007) reported that yeast addition increased nutritional value of poor quality forages, improved feed intake and milk yield in dairy cows.

Table.4. Milk yields and milk composition of lactating cows fed on experimental rations (mean \pm SE).

\begin{tabular}{|c|c|c|c|c|c|c|}
\hline Item & FTH & HTH & $\mathrm{HTH}+\mathrm{F}$ & $\mathrm{SHT}$ & $\mathrm{STH}+\mathrm{B}$ & $\mathrm{STH}+\mathrm{B}+\mathrm{Y}$ \\
\hline $\begin{array}{l}\text { Milk yields, } \\
\mathrm{kg} / \mathrm{d}\end{array}$ & $11.14 \pm 0.89^{d}$ & $11.50 \pm 0.65^{d}$ & $15.30 \pm 0.65^{\mathrm{a}}$ & $13.30 \pm 0.95^{c}$ & $14.00 \pm 0.45^{b}$ & $15.04 \pm 0.89^{a}$ \\
\hline $4 \% \mathrm{FCM}^{*}$ & $9.56 \pm 0.40^{d}$ & $10.60 \pm 0.24^{c}$ & $14.07 \pm 0.24^{a}$ & $11.93 \pm 0.62^{b}$ & $10.92 \pm 0.61^{c}$ & $13.82 \pm 0.40^{a}$ \\
\hline Fat, $\mathrm{kg} / \mathrm{d}$ & $0.34 \pm 0.01^{c}$ & $0.40 \pm 0.01^{b}$ & $0.53 \pm 0.01^{a}$ & $0.44 \pm 0.02^{b}$ & $0.44 \pm 0.52^{b}$ & $.0 .52 \pm 0.01^{a}$ \\
\hline Protein, $\mathrm{kg} / \mathrm{d}$ & $0.36 \pm 0.03^{d}$ & $0.40 \pm 0.02^{c}$ & $0.53 \pm 0.02^{a}$ & $0.48 \pm 0.05^{b}$ & $0.49 \pm 0.03^{b}$ & $0.58 \pm 0.03^{a}$ \\
\hline \multicolumn{7}{|c|}{ Milk composition (\%). } \\
\hline Total solids & $11.10 \pm 0.89^{b}$ & $12.08 \pm 0.11^{\mathrm{a}}$ & $12.58 \pm 0.14^{\mathrm{a}}$ & $12.01 \pm 0.28^{a}$ & $12.30 \pm 0.14^{\mathrm{a}}$ & $12.44 \pm 0.89^{a}$ \\
\hline Solids not fat & $8.16 \pm 0.40^{a}$ & $8.61 \pm 0.25^{a}$ & $8.95 \pm 0.12^{a}$ & $8.72 \pm 0.24^{\mathrm{a}}$ & $8.09 \pm 0.12^{a}$ & $8.88 \pm 0.40^{a}$ \\
\hline Fat & $3.1 \pm 0.01$ & $3.45 \pm 0.22$ & $3.52 \pm 0.12$ & $3.30 \pm 0.18$ & $3.48 \pm 0.12$ & $3.50 \pm 0.01$ \\
\hline Protein & $3.39 \pm 0.03$ & $3.50 \pm 0.13$ & $3.88 \pm 0.21$ & $3.67 \pm 0.19$ & $3.70 \pm 0.21$ & $3.90 \pm 0.03$ \\
\hline Lactose & $3.54 \pm 0.89$ & $4.10 \pm 0.29$ & $3.99 \pm 0.26$ & $4.00 \pm 0.39$ & $3.89 \pm 0.26$ & $4.01 \pm 0.89$ \\
\hline Ash & $0.98 \pm 0.40^{c}$ & $1.00 \pm 0.04^{\mathrm{ab}}$ & $1.12 \pm 0.03^{a}$ & $1.10 \pm 0.06^{\mathrm{ab}}$ & $1.03 \pm 0.03^{a}$ & $1.02 \pm 0.40^{c}$ \\
\hline
\end{tabular}

abdc Means within rows with different superscript are significantly differ $(\mathrm{P}<0.05)$.

CFM: Concentrate fed mixture, FTH: Fresh tomato haulm, HTH: Hay tomato haulm, HTH+F: Hay tomato haulm treated with fungi, STH: Tomato haulm silage, STH+B: Tomato haulm silage with bacteria, $\mathrm{STH}+\mathrm{B}+\mathrm{Y}$ : tomato haulm silage with bacteria+ dried yeast.

$* 4 \%$ FCM was calculated as: $0.4 X$ milk yield $(\mathrm{kg})+15 \mathrm{X}$ fat yield $(\mathrm{kg})$. Gaines (1923).

Concentration of pesticides residue and total polychlorinated biphenyls (PCBs) in milk. 
Concentration of pesticides residue and total PCBs ( $\mu \mathrm{g} / \mathrm{kg}$ on fat basis) in cows milk are presented in Table 5. The pesticides residue and total PCBs in the milk of cows fed THF and THS and THS+B and THS+B+DY rations showed lower values of pesticides residue compared to the other rations. DebMandal et al. (2008) reported that microbes (fungi, bacteria, and other microorganisms) could degrade or breakdown the pesticides whereas they used them as feed source.

Table.5. Concentration of pesticides residue and total PCBs ( $\mu \mathrm{g} / \mathrm{kg}$ on fat basis) of the milk cows samples.

\begin{tabular}{|c|l|l|l|l|l|l|}
\hline Item & \multicolumn{1}{|c|}{$\mathrm{FTH}$} & \multicolumn{1}{|c|}{$\mathrm{HTH}$} & \multicolumn{1}{|c|}{$\mathrm{HTH}+\mathrm{F}$} & \multicolumn{1}{|c|}{ SHT } & STH+B & STH+B+Y \\
\hline Cypermethrin & 0.21 & 0.005 & 0.004 & 0.004 & N.D & N.D \\
\hline Dimethoate & 0.49 & 0.14 & N.D & N.D & N.D & N.D \\
\hline Malathion & 0.78 & 0.056 & N.D & N.D & N.D & N.D \\
\hline HCB & 0.003 & N.D & N.D & N.D & N.D & N.D \\
\hline Lindine & 0.019 & 0.001 & 0.003 & 0.002 & N.D & N.D \\
\hline p.p' DDE & 0.021 & 0.004 & N.D & 0.001 & 0.001 & N.D \\
\hline Total PCBs & 0.44 & 0.09 & N.D & N.D & 0.03 & 0.01 \\
\hline
\end{tabular}

CFM: Concentrate feed mixture, FTH: Fresh tomato haulm, HTH: Hay tomato haulm, $\mathrm{HTH}+\mathrm{F}$ : Hay tomato haulm treated with fungi, STH: Tomato haulm silage, STH+B: Tomato haulm silage with bacteria, $\mathrm{STH}+\mathrm{B}+\mathrm{Y}$ : tomato haulm silage with bacteria+ dried yeast.

HCB: Hexo chloro benzene DDE: Diphenyldichloroendosulfan.N.D: not detected

\section{Blood biochemical and serum constituents}

There was increase of glucose and cholesterol in the serum of animals fed fresh $\mathrm{TH}$, while less value were demonstrated for animals fed $\mathrm{TH}$ treated with fungi or preserved as silage (Table6). The later had higher $(P<0.05)$ concentration of TP and albumin, while they had lower $(P<0.05)$ globulin. On the other hand, animals fed fresh $\mathrm{TH}$ had higher $(\mathrm{P}<0.05)$ concentration of urea, creatinine, AST and ALT compared to the other experimental groups. However, the changes in carbohydrate metabolism induced by pesticides can be correlated with the effects of these chemicals on the activities of hepatic enzyme system which are intimately involved in glucose production, storage and metabolism and/or correlated with the endocrine activity of the pancreas (insulin activity). 
Table. 6. Blood serum parameters of lactating cows fed experimental ration (mean \pm SE).

\begin{tabular}{|c|c|c|c|c|c|c|}
\hline Item & FTH & HTH & $\mathrm{HTH}+\mathrm{F}$ & SHT & $\mathrm{STH}+\mathrm{B}$ & $\mathrm{STH}+\mathrm{B}+\mathrm{Y}$ \\
\hline Glucose mg/dl & $128.62 \pm 4.82^{\mathrm{a}}$ & $95.55 \pm 2.44^{b}$ & $80.45 \pm 3.70^{c}$ & $82.64 \pm 2.96^{c}$ & $81.33 \pm 2.96^{c}$ & $80.04 \pm 2.96^{c}$ \\
\hline Cholesterol mg/dl & $201.55 \pm 8.34^{a}$ & $180.02 \pm 3.98^{b}$ & $90.94 \pm 3.22^{c}$ & $95.40 \pm 2.77^{c}$ & $93.34 \pm 2.77^{c}$ & $94.50 \pm 2.77^{c}$ \\
\hline TP g/dl & $6.33 \pm 0.22^{b}$ & $6.48 \pm 0.63^{b}$ & $8.00 \pm 0.41^{a}$ & $8.08 \pm 0.27^{a}$ & $8.03 \pm 0.27^{a}$ & $8.06 \pm 0.27^{a}$ \\
\hline Albumin g/dl & $3.32 \pm 0.11^{c}$ & $3.56 \pm 0.18^{c}$ & $4.97 \pm 0.23^{a}$ & $4.55 \pm 0.13^{b}$ & $4.04 \pm 0.13^{a}$ & $4.80 \pm 0.13^{a}$ \\
\hline Globulin g/dl & $3.22 \pm 0.09^{a}$ & $3 . .09 \pm 0.07^{a}$ & $2.83 \pm 0.13^{b}$ & $2.86 \pm 0.05^{\mathrm{a}}$ & $2.97 \pm 0.05^{b}$ & $2.96 \pm 0.05^{b}$ \\
\hline Urea mg/dl & $60.00 \pm 3.22^{\mathrm{a}}$ & $52.04 \pm 3.43^{b}$ & $45.01 \pm 2.52^{c}$ & $43.44 \pm 2.88^{c}$ & $44.43 \pm 2.88^{c}$ & $43.20 \pm 2.88^{c}$ \\
\hline Creatinine, mg/dl & $1.84 \pm 0.05^{\mathrm{a}}$ & $1.58 \pm 0.08^{a}$ & $1.11 \pm 0.01^{b}$ & $1.11 \pm 0.03^{b}$ & $1.12 \pm 0.03^{b}$ & $1.03 \pm 0.03^{c}$ \\
\hline AST U/L & $55.53 \pm 3.63^{a}$ & $49.53 \pm 2.88^{b}$ & $35.02 \pm 2.54^{c}$ & $33.00 \pm 2.72^{c}$ & $33.01 \pm 2.72^{c}$ & $33.11 \pm 2.72^{c}$ \\
\hline ALT U/L & $21.09 \pm 1.56^{\mathrm{a}}$ & $20.05 \pm 1.13^{a}$ & $13.99 \pm 1.25^{b}$ & $13.04 \pm 1.43^{b}$ & $13.09 \pm 1.43^{b}$ & $13.09 \pm 1.43^{b}$ \\
\hline
\end{tabular}

abc Means within rows with different superscript are significantly differ $(P<0.05)$.

CFM: Concentrate fed mixture, FTH: Fresh tomato haulm, HTH: Hay tomato haulm, $\mathrm{HTH}+\mathrm{F}$ : Hay tomato haulm treated with fungi, STH: Tomato haulm silage, STH+B: Tomato haulm silage with bacteria, $\mathrm{STH}+\mathrm{B}+\mathrm{Y}$ : tomato haulm silage with bacteria+ dried yeast.

Exposure of animals to pesticides may interfere with transport of glucose that crosses the gastrointestinal canal. Thus, daily administration of propoxur (carbamate pesticide) at 0.1 LD50 resulted in increasing transport and decreasing absorption of glucose in the small intestines.

The reduction of serum proteins, particularly albumin, in animals fed FTH treated with pesticides could be attributed to changes in protein and free amino acid metabolism and their synthesis in the liver (Rivarola and Blegno, 1991).

\section{CONCLUSION}

Conclusively, it could be advisable to use biological treatment with fungi. In order to overcome the harmful effect of feeding TH exposure to pesticide, bacteria (silage) or bacteria (silage) with dried yeast. However, more studies are needed in this aspect. 


\section{REFERENCES}

1. Agricultural Statistics, Economic Affairs Sector, Ministry of Agriculture (2006/2007).

2. Allam, S. M., Hoda, M. El-Hosseiny, M. Fadel, H. M. El-Banna and A R. Refai (2006). Nutrients utilization and growth performance of lambs fed rations containing corn stover treated chemically and biologically. J. Agric. Sci. Monsoura Univ., 31: 1993.

3. AOAC, .1990. Official Methods of analysis. 15th Ed. Association of Analytical Chemists, Washington, DC.

4. DebMandal, M., M. Shyamapada and K. Nishith, 2008. Potential metabolites of dimethoate produced by bacterial degradation. World Journal of Microbiology and Biotechnology, 24: 69-72.

5. El-Shazly, K., H. A. Ahmed, M. A. Naga and B. E. A. Borhami.1976. A colorimetric techniqe using chromium ethylene diamine tetraacetate for measuring rumen volume. J. Agric. Sci. Camb., 87: 369.

6. El-Waziry A.M. and H. R. Ibrahim.2007.Effect of Saccharomyces cerevisiae yeast on Fiber Digestion in Sheep Fed Berseem (Trifolium alexandrinum) Hay and Cellulase Activity. Aus. J. of Basic and Appl. Sci. 1(4): 379-385.

7. Henry, J. B. and Todd, S. D. 1974. Clinical Diagnosis and Measurement by Laboratory Methods., 16th Ed., W. B. Saunders and Co., Phliadephia., PA. P 260.

8. Jouany, J. P. and D. P. Morgavi. 2007. Use of 'natural' products as alternatives to antibiotic feed additives in ruminant production. Animal Journal (10): 1443-1466.

9. Kadenczki, L., Arpad, Z., Gardi, I, Ambrus, A, Gyorfi, L., Reese, G. and Ebing, W. 1992. Column extraction of residues of several pesticides from fruits and vegetables: A simple multiresidue analysis method. J. AOAC. 75: 53-61.

10. Kumar, U., V. K. Sareen and S. Singh. 1997. Effect of yeast culture supplement on ruminal microbial population and metabolism in buffalo calves fed high roughage diet. J. of Sci. food and Agric., 73: 231.

11. McDonald, I. 1981. A revised model for the estimation of protein degradability in the rumen. J. Agric. Sci. Camb., 96: 251

12. Maynard, L. A., Loosli, U. K., Hintz, H. F. and Warner, R. G. 1978. Animal Nutrition. (7th Ed.) Mcgraw. Hill Book Co., New York.

13. Nevalainen, K. M., M. E. Penttila, A. Harkki and T. T. Teeri. 1991. The molecular biology $t-f$ Trichoderma and its application to the expression of both homologous and heterologous genes, p. 179-148. in S. A. Leong and R. M. Berka (ed.), Moleculor IndustrialMycolagy. Marcel Dekker, Inc., New York, N.Y. 
14. NRC. 1990. Nutrient Requirements of Dairy Cattle. $7^{\text {th }}$ ed. National Research Council. National Academy Press. Washington, D. C., USA.

15. Ørskov, E. R. and McDonald, I. 1979. The estimation of protein deradability in the rumen from incubation measurements weighed according to rate of passage. J. Agric. Sci. Cambridge. 92: 499-503.

16. Ørskov, E.R. 1992. Protein Nutrition in Ruminants. 2 ed. Academic Press, Inc., San Diego, CA.

17. Rivarola, V. A. and Balegno, H. F. 1991. Effects of 2, 4-dichlorophenoxyacetic acid polyamine synthesis in Chinese hamster ovary cells. Toxicol. Lett., 56: 151-157.

18. SAS Institute Inc. 1999. SAS User's Guide. SAS Institute Inc., Cary, NC.Stein, E. A. 1986. Textbook of Clinical Chemistry, NW Tietz, ed. W. B. Saunders, Philadelphia, pp. 879-886, 1818-1829.

19. Van Soest, P.J. 1982. Nutritional ecology of the ruminant. O and B Books Inc., Corvallis, Oregon. Pp. 112, 126 and 127.

20. Wallace, R. J. and C. J. Newbold.1993. Rumen fermentation and its manipulation the development of yeast culture on feed additives. In T.P.Lyons (Ed) Biotechnology in the feed industry. PP.173 Allttech Technical Publication, Nicholasville, Ky USA. 
دراسة عن إستخدام عروش الطماطم فى تفذية المجترات

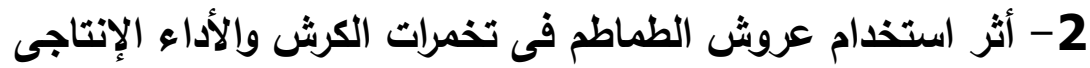

للأبقار الحلابة

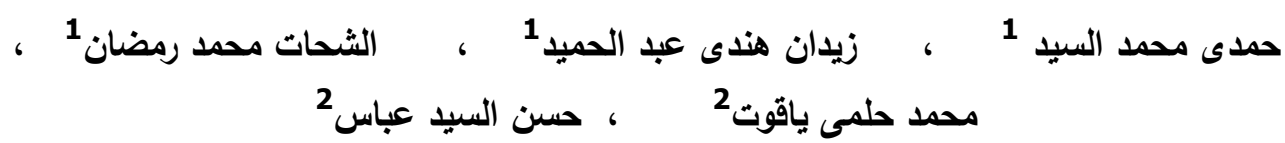

1 1. 1 كلية الزراعة - جامعة عين شعس.

2. دعهُ بحوث الانتاج الحيوانى - مركز البحوث الزراعية - وزارة الزراعة

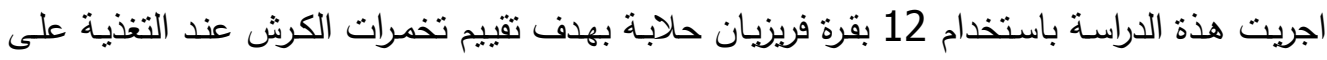

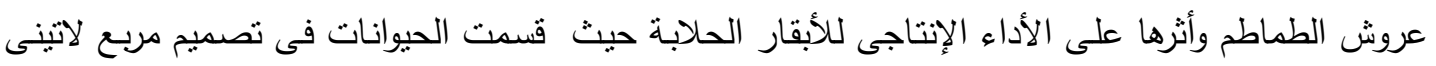

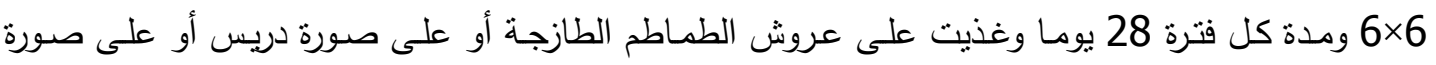

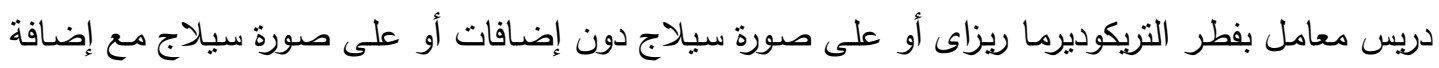

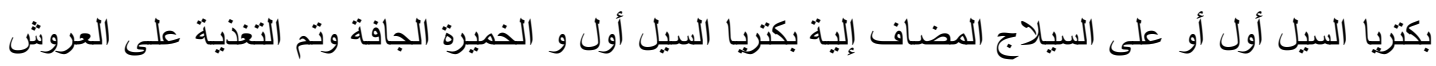
بصورة حرة وغذيت النعاج المزودة بفستيولات الكرش على 750 جم علف مركز للرأس أما الأبقار فقدم لها 8 كجم علف مركز للرأس وإضافه الخميره الجافه إلى العلف المركز بمعدل 5جم/رأس أغنام و 10 جم / بقرة. هذا وقد أظهرت تخمرات الكرش زيادة تركيزات الأمونيا مـع العلائق المحتويـة على عروش الطهاطم

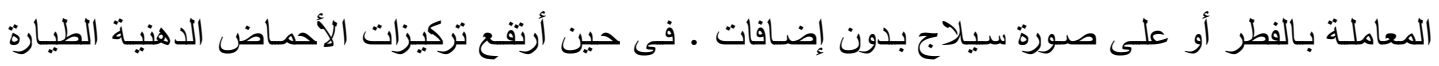

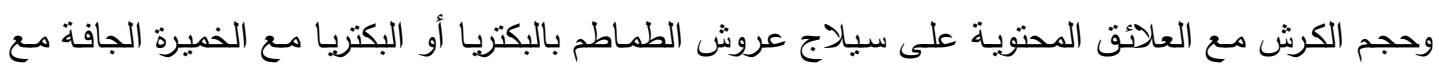

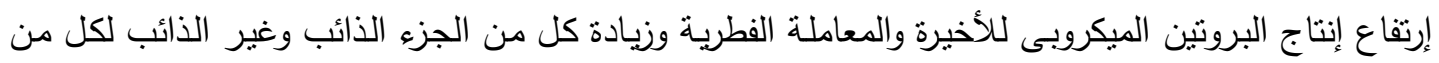

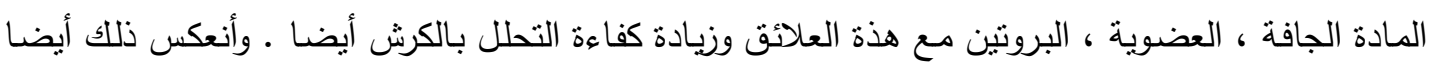

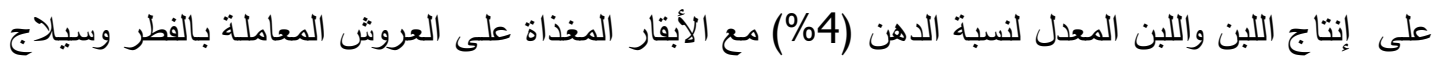

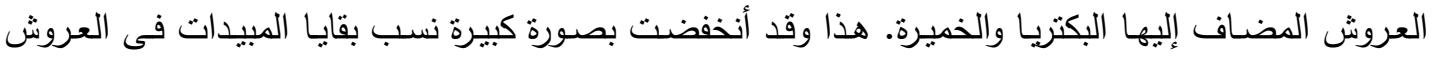

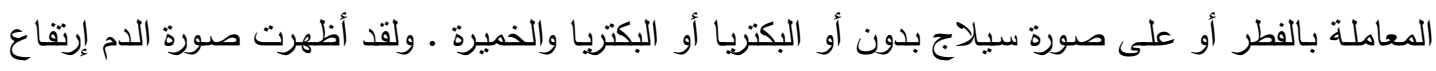

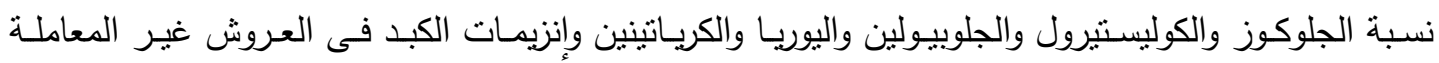
وأنخفضت هذة التركيزات بعد المعاملة بالفطر أو السيلجة وأقتربت كثيرا من معدلاتها الطبيعية. بناءا على ماسبق ينصح بمعاملة عروش الطماطم بفطر التريكوديرما ريزاى أو سيلجتها خاصة بإضافة

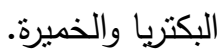

